DOI: $10.33276 / 978-5-8211-0794-7-116-122$

B.H. Yerznkyan, K.A. Fontana

Yerznkyan Bagrat H., dr. econ., prof., head of lab., CEMI RAS, Moscow, lvova1955@mail.ru

Fontana Karine A., cand.econ., senior researcher, CEMI RAS, Moscow, fontana@mail.ru

\title{
GOVERNING WATER AND ENERGY AS SPECIFIC RESOURSES
}

\begin{abstract}
Water and energy are resources without which it is impossible to present, at least, neither functioning of industrial enterprises nor existence of housekeepings. In terms of Oliver Williamson they are the typical resources (assets) of the general setting. Cases are at the same time possible, when they come forward as resources, alternative to generally accepted, namely: they appear in a role of specific resources. Reasons for it can be various, depending on the specificity of the concrete situation. As in the case of specific resources (assets) risks are great, it causes the special system requirements management such by water and energy. This paper is devoted to the exposure of features of these requirements.

Keywords: water, energy, specific resourses (assets), governing.

JEL Classification: B52, D23, P48, Q53.
\end{abstract}

\section{INTRODUCTION}

Energy and water, understood in the traditional sense, are general-purpose resources (assets) that can be used without special risks - both for their suppliers (producers) and consumers. Such assets are contrasted with specific assets that are "the result of a specialized investment" that cannot be repurposed by "users without loss of their productive potential" (Williamson, 1996, p. 689). This work proceeds from the assumption that alternative energy supply and alternative water supply are able to fill the shortage of both energy and water, respectively, where it is possible to implement technologically and where it is expedient to implement it from an economic point of view. Alternatively, the produced energy and water resources in this case are not general but specialized assets. The appeal to an alternative can be caused by various reasons. For example, countries that do not have their own traditional resources or have them in limited quantities will try to make up for their absence or shortage by resorting to alternative methods of generating them.

The main difference between alternative energy and traditional energy is that the energy generated by the traditional method is produced for an impersonal consumer and can be transmitted over great distances. Alternative energy is produced not as such in general, but personified, for a specific consumer; as a rule, energy production and consumption enterprises are adjacent and / or interconnected with each other. In Oliver Williamson's terms, alternative energy is a specific asset by location - where it is produced by some and consumed by other economic agents (enterprises). At the same time, the specificity of alternative energy means the presence of high risks (with low generation), while its absence in traditional energy implies the absence of risks (with high generation). We are talking about the risks of con- 
tracting between the manufacturing enterprise and the consumer enterprise. If this reasoning is correct, then one should think about protective mechanisms or guarantees against potential risks.

\section{AlternAtive ENERGETIC RESOURSES}

Alternative energy production faces significant institutional barriers, especially in Russia. This is partly due to the lack of adequate institutions, primarily formal ones, partly the lack of appropriate motivation on the part of regulators for such production due to the abundance of traditional energy sources in the country, which are, recall, general-purpose assets. So, in her Ph.D. thesis, G.N. Ryazanova (2015) gives an example of how the disinterest of those who supply diesel engines, i.e. traditional provision can serve as an obstacle to the introduction of windmills as an alternative source. At the same time, it is important to realize that the institutional side must be supported technologically and that a harmonious combination of both sides is necessary, and the basis of the institutional relationship must be the coordinated actions of economic entities in the socio-economic space with the distribution (regulation) of the roles of each of them for sustainable functioning systems. At the same time, the problem lies in the fact that today the institutional structure - both the energy sector and the water supply sector - is at the stage of formation.

Generally speaking, the process of institutionalization is not just long-term; it requires changes not only in the institutional system, but also in the mentality of economic agents - carriers of institutions. Academician D.S. Lvov has repeatedly spoken about the need to adjust the consciousness of people, their mentality, as an indispensable condition for the implementation of large-scale reforms (see, for example, Lvov, 2000; 2002; 2006; 2008). He invariably emphasized that "in the course of reforms, it is necessary to rebuild not only reality itself - the economy, but to correct the subjective attitude of people to this reality, that is, to transform the image of the social world that prevails in the minds of citizens" (Lvov, 2006, p. 19).

Of course, there is a significant difference between large-scale socio-economic reform and the transition to alternative resource sources, but on a local scale of contracting between counterparties - producers and consumers of alternative resources, if there was no understanding on their part and awareness of the importance of the process of transition to an alternative for them, the expected success was hardly possible.

Developments based on alternative sources, conducted from the point of view of the perspective as such, or local demand for them in particular, may differ from traditional developments in the motivational aspect for the better. In the latter case, positive motivation can be found in specific individuals (bodies, organizations) interested in solving the problem of providing themselves with resources available to them, obtained in an alternative way on a local scale. The need for an alternative is caused by the special geographic and demographic conditions of Russia - 2/3 of the country's territory with unique natural resources is located in the permafrost zone, the population density of which is very low, which complicates both 
the extraction of energy resources and the solution of the issue of energy supply to the population of hard-to-reach regions of the country, where it is impossible centralized supply of electricity to consumers.

Due to the impossibility of combining energy supply facilities in such areas into network structures, their solution to this problem naturally arises through the construction of local power plants along with the development of alternative energy sources. The same is true for alternative water supplies.

\section{Alternative WATER Resourses}

Traditional methods of water supply by reducing the specific consumption of water resources, reducing water losses during transportation in water supply and drainage systems (including through the reconstruction and modernization of water supply and sewerage facilities), reconstruction of various types of systems, including irrigation, at present are not sufficient. In agriculture, this is expressed in the need to irrigate crops (food and non-food), gardens and pastures, when growing aquaculture (including algae), in fishing ponds, etc. In industry, where the main consumers of water are the chemical, pulp and paper, steel and metallurgical industries; water resources are used in cooling systems, for making concrete, for dust management, for soil compaction, etc. In municipalities, water is used for irrigation of public parks, recreational and sports facilities, for washing roads and cleaning streets, in fire protection systems, for washing cars, heating systems and air conditioning systems; when flushing in toilets in commercial and public places; for snowmaking; during the operation of fountains, etc. This list can be continued.

It is important that a transition to alternative water supply methods is necessary, which are based, in particular, on waste water treatment (WWS) and reuse (PI) of treated water. There is a widespread point of view that PI water as an alternative source of water supply and one of the directions of sustainable development in the long term has more advantages than disadvantages, and with the development of new technologies it can become the main and most economically profitable (PWC, 2000). Whether this is so or not, the future will show; in any case, everything should be decided taking into account the specific circumstances.

We also emphasize that the noted systematic generation of clean water from the already used one underlies the circular economy. Unfortunately, there are many obstacles on the way to its implementation, including those of an institutional nature. So, for example, such issues were not reflected either in the Water Code, or in the Water Strategy of the Russian Federation, or in other legislative acts, in the programs of the Central Exhibition Complex.

\section{GOVERNING WATER AND ENERGY: SOME PARALLELS}

For governing, say, treated wastewater reuse there are not unified rules and leading principles neither in Russia, nor in abroad. To prepare unified rules is rather insoluble prob- 
lem, especially when taking into account the cultural and institutional differences of countries. Such is true not only to the connection of water reuse. Water in contemporary Russia is counted rather as the expence material than the main resource for life-support of population. "Water reuse of effluents is not examined in a number priority at the decision of ecological and socio-economic tasks, and also as an important element of steady development of water resources. Earlier, in the USSR, for water treatment were used methods that were well shown themselves, including from the point of view of capital investments in sewage treatment plants and their subsequent exploitation, and also positive influence on chemical composition and agro-melioration properties of irrigable soils, productivity of rural economy cultures. The similar systems and practices were recommended to wide introduction in practice of agricultures production, but however in future wide distribution of treated wastewater reuse did not get" (Yerznkyan, Fontana, 2020, p. 21).

Let's draw some parallels between alternatively generated energy and water resources as well as to the specificity of their governing.

Specificity by location: alternative methods of energy supply and water supply are characterized primarily by this form of specificity. It is the proximity of waste, converted into normal resources, to producers and consumers that push them towards mutually beneficial cooperation.

The problem of negative side effects is solved not so much as such, but rather as necessary for the production and consumption of alternative resources. For example, water, being a public or quasi-public good, is at the same time a meritorious good (the demand for which by economic agents does not coincide with the normative attitudes of society) (Musgrave, 1987), which, as a result of pollution, can turn into a demerit good.

To prevent the demeritorization of water, either protective governing mechanisms are needed, say, in the form of state guardianship, or other ways of solving the problem of negative externalities. One of such effective ways of solving the problem of not only negative, but also its transformation into positive, can be the transition to alternative methods of water supply.

From the standpoint of meritorism, the purification of wastewater for their subsequent use is similar to the remerization of a water benefit. In passing, we note that with all the similarity of the concepts of public and meritorious goods, it is advisable not to mix them. Alexander Rubinstein, defending this point of view, proposes such a definition of meritor goods: they are «goods, the demand for which from private individuals lags behind the» desired by society «and is stimulated by the state.» In contrast, demerit goods are understood as «goods and services, the consumption of which the state seeks to reduce, using appropriate institutional instruments» (Rubinstein, 2018, p. 162).

Let's give an example of negative side effects from the field of energy supply. Many owners of agricultural enterprises are concerned not so much with the constant rise in prices for energy resources and unstable centralized energy supply, but with the environmental haz- 
ard of animal waste, which poison not only the area of the enterprise itself, but also the soil and water bodies adjacent to it, causing diseases of animals and humans.

But when turning to an alternative, livestock complexes can become serious suppliers of resources for energy supply through waste disposal. It is only necessary, according to G.N. Ryazanova (2015), to be able to convert the problem into an energy resource, taking into account the multifactorial value of utilized waste, which can be used to obtain biogas and create its own autonomous energy system, as well as to produce organic fertilizers that are unique in their properties.

An alternative as a way of solving, in addition to purely economic (agriculture, industry, urban economy), also environmental problems (reducing wastewater discharge into water bodies and / or preventing wastewater from entering sensitive water bodies, increasing the flow, replenishing the aquifer and artificial reservoirs, reducing water intake from natural water sources, etc.).

A circular economy serves to represent a type of economy based on the use of renewable resources - for example, energy, water - and «opposed in this sense to the traditional, linear economy based on the creation, use and disposal of them» (Yerznkyan, Fontana, 2018). In the situation with water, the circular nature of the economy is manifested in the PI WWS. Barriers to the implementation of its principles in Russia are: "lack of incentives to introduce innovative technologies and methods of water supply; institutional provision of wastewater reuse inadequate to local conditions and technological solutions; weak linking of the policy pursued by the city (municipal) authorities with the essence of specific problems of PI, etc.» (Ibid.).

Earlier, we talked about an institutional gap that hinders the provision of adequate energy and water supplies. It should be clarified that it was primarily about the legal gap affecting the regulatory market of the alternative economy in relation to water and energy resources. To this we add the gap of attention and interest on the part of society and business, because if there is no demand from them for alternative types of resources (it does not matter because of their cost or due to ignorance about alternatives), then it is difficult to expect that they will appear.

On a global scale, it is difficult to expect to solve this problem of filling the gaps and expanding the supply of alternative resources without state support and state orders. In fact, we are talking about the performance by the state of paternalistic functions in relation to public and meritorious goods. At the same time, bearing in mind the virtually destroyed state of «the powerful diversified production potential of the country created in Soviet times, the closure of tens of thousands of enterprises, the emergence of significant unemployment that was previously absent» (Livshits, Livshits, 2018, p. 113) and other factors hindering the emergence of a sustainable a stationary mode of functioning of the economy, one should hardly rely solely on the state. The search should be conducted in the direction of finding alternative solutions. 
What is the difference between the solution proposed in this article and the "global" solution is that an internal (internalized) solution is proposed, without resorting to state custody, in other words, a "local" solution, in which potential producers and resource consumers. In a sense, this decision can be considered based on an extended interpretation of Coase's theorem: stakeholders who can agree without significant transaction costs of interaction and without special legal delays are able to achieve the Pareto optimal result. Of course, it is difficult to do this on a national scale, but on a local scale - taking into account the specificity of assets by location - it is possible, fortunately, this is evidenced by the existing examples worthy of imitation, which can be found, among other things, in the works of A.A. Zardnadze, B.H. Yerznkyan, G.R. Ryazanova and K.A. Fontana.

\section{REFERENCES}

Fontana K.A., Yerznkyan B.H. Reuse of water as an element of a circular economy in the light of the imperatives of N.N. Moiseev and D.S. Lvov // Lvov Readings - 2019 [Text]: collection of articles of the VII All-Russian Scientific Conference / Ed. by Corresponding Member of RAS G.B. Kleiner; State University of Management, Institute of Economics and Finance, State University of Management, Department of Institutional Economics. - Moscow: GUU Publishing House, 2019. P. 338-343.

Livshits V.N., Livshits S.V. Seven stages of radical reform of the Russian economy and society and seven «development manifestos» from leading economists and sociologists // Bulletin of the Institute of Economics of the Russian Academy of Sciences. 2018. No. 2. P. 112-124.

Lvov D.S. Prospects for the development of the Russian economy. Moscow: Russian Academy of Sciences. Department of Economics, 2000. 138 p.

Lvov D.S. Development economics. Moscow: Examination, 2002. 512 p.

Lvov D.S. Mission of Russia (Civil Manifesto). Moscow: Institute for Economic Strategies, 2006. 56 p.

Lvov D.S. Mission of Russia [Text]: Collection of scientific papers / State University of Management; [under scientific. ed. By S.Yu. Glazyev and B.H. Yerznkyan]. Moscow: GUU, 2008. 120 p.

Rubinstein A.Ya. The theory of patronized goods: a textbook. SPb.: Aleteya, 2018. 304 p.

Ryazanova G.N. Institutional aspects of alternative energy supply for enterprises in the national economy. Abstract dissertation. to apply for an account. degree of Cand. econom. sciences. Moscow: TsEMI RAN, 2015.

Musgrave R.A. Merit Goods. In: Eatwell J., Milgate M., Newman P. (eds.). The New Palgrave: A Dictionary of Economics. London: Basingstoke Macmillan, 1987. P. 452-453.

Williamson O.E. The economic institutions of capitalism: Firms, markets, «relational contracting». SPb.: Lenizdat; CEV Press, 1996. 702 p.

Zarnadze A.A., Ryazanova G.N. The value of RES technologies for the development of the Russian economy // Theory and practice of institutional reforms in Russia / Collection of scientific works, by ed. B.H. Yerznkyan. Issue 34. Moscow: CEMI RAN, 2015. P. 119-128.

Yerznkyan B.H., Fontana K.A. Institutional aspects of the development of a circular economy in the field of water supply // Vestnik TsEMI RAN. 2018. Issue 1 [Electronic resource]. URL: http://cemi.jes.su/s111111110000079-9-1. DOI: 10.18254/S0000079-9-1.

Yerznkyan B.H., Fontana K.A.Technological and Institutional Aspects of Water Reuse Regulation // Materials of the International Conference "Process Management and Scientific Developments" (Birmingham, United Kingdom, March 31, 2020). Scientific publishing house Infinity, 2020. P. 19-27. DOI: $10.34660 /$ INF.2020.7.58879 
Ерзикян Б.А., Фонтана К.А.

УПРАВЛЕНИЕ ВОДОЙ И ЭНЕРГИЕЙ КАК СПЕЦИФИЧЕСКИМИ РЕСУРСАМИ

Вода и энергия являются ресурсами, без которых невозможно себе представить, по меньшей мере, ни функционирование промышленных предприятий, ни существование домашних хозяйств. В терминах Оливера Уильямсона - это типичные ресурсы (активы) общего назначения. Вместе с тем возможны случаи, когда они выступают в качестве ресурсов, альтернативных общепринятым, а именно: они предстают в роли специфических ресурсов. На это могут быть свои причины, зависящие от специфики конкретной ситуации. Поскольку в случае специфических ресурсов (активов) велики риски, это вызывает особые требования к системе управления такого рода водой и энергией. Выявлению особенностей этих требований и посвящена настоящая статья.

Ключевые слова: вода, энергия, специфические ресурсы (активы), управление.

JEL классификация: B52, D23, P48, Q53. 